Corresponding Author: Oleg Vadimovich Zayakin zferro@mail.ru

Received: 5 February 2019 Accepted: 6 March 2019 Published: 17 March 2019

Publishing services provided by Knowledge

(c) Oleg Vadimovich Zayakin et al. This article is distributed under the terms of the Commons Attribution License, which permits unrestricted use and redistribution provided that the original author and source are credited.

Selection and Peer-review under the responsibility of the NIOKR-2018 Conference Committee.

\section{Simulation of the Melting Process for Complex Nickel-containing Ferroalloys in Steel}

\section{Oleg Vadimovich Zayakin¹, Vladimir Ivanovich Zhuchkov¹, and Elizaveta Yurievna Lozovaya²}

${ }^{1}$ Institute of Metallurgy of the Ural Branch of the Russian Academy of Science, Yekaterinburg, Russia, Yekaterinburg, Sverdlovsk region, Russia

${ }^{2}$ Federal State Autonomous Educational Institution of Higher Education, Ural Federal University named after the first President of Russia B.N. Yeltsin, Yekaterinburg, Sverdlovsk region, Russia

\section{Abstract}

In this study, the melting process simulation for the complex nickel-, silicon-containing ferroalloys in a steel melt was performed. For the study, complex ferroalloys samples ( 10\% Ni, 5-56\% Si) were selected, by composition corresponding to the alloys, which can be smelted from poor Russian oxidized nickel ores. It is shown that all the alloys under consideration belong to the group of low-melting ferroalloys, in which the liquidus temperature $\left(T_{l}\right)$ does not exceed the crystallization of the iron-carbon melt $\left(T_{c m}\right)$. The process of their melting in an iron-carbon melt takes place in three periods. During the first period, the ferroalloy warms up and when the surface temperature reaches $T_{l}$, it begins to melt. In this case, ferroalloy pieces are in the shell of solid steel, the thickness of which increases at the beginning of the period and decreases toward the end. It was revealed that an increase in the fraction of all the alloys under consideration from 1 to $50 \mathrm{~mm}$ leads to a stable increase in the melting time $(\tau)$. It is shown that increasing the silicon concentration from 5 to $18 \%$ reduces $\tau$, a further growth of the Si content up to $31 \%$, on the contrary, is accompanied by an increase of $\tau$ in the alloys, and a subsequent increase in $\mathrm{Si}$ to $53 \%$ leads to a gradual reduction of $\tau$. In general, complex nickel-, silicon-containing ferroalloys are characterized by a much faster melting process course in steel compared to ferronickel.

Keywords: metallurgy, ferroalloys, steel, melting time, thermophysical properties

\section{Introduction}

One of the nickel industry problems in our country is a sharp decrease in the extraction and processing of oxidized nickel ores (ONO). In 2010 ores of four deposits were developed and the nickel share from the ONO in Russian production reached $10 \%$ but in recent years mining operations have been carried out on only one deposit, and production does not exceed 5\% [1]. The current situation is mainly due to the lack of profitable technologies for the extraction and processing of oxidized nickel ores. At the same time, 
in recent years, the production of nickel-containing alloys and steels has significantly increased in the world. In Russia, electrolytic nickel ( $\sim 99 \% \mathrm{Ni})$ is mainly used for their smelting, the high price of which does not contribute to the development of the production of nickel-containing steels [2]. At the same time, in our country, there is a shortage of relatively cheap nickel and complex ferroalloys containing $10-30 \% \mathrm{Ni}[3,4]$, which can be produced from domestic ONO [5, 6]. At present, a number of methods have been developed [7], which make it possible to efficiently process poor oxidized nickel ores with the production of new types of ferroalloys [8, 9], however, such alloys are still in low demand in steelmaking. To use new ferroalloys in the processing of steel, it is necessary to know their physicochemical characteristics. One of the most important characteristics of the alloy intended for steel alloying is the time of its melting and dissolution in the iron-carbon melt [10], on which depend both the absorption and the distribution of the leading elements of the ferroalloy in the metal volume [11, 12]. The mechanism of alloys melting is a fundamental factor determining the time of its melting in an iron-carbon melt [13]. Extensive research was conducted in this area by both domestic [11, 14, 15] and foreign $[12,16-21]$ metallurgists.

In this work, to study the melting process of complex nickel-containing alloys in an iron-carbon melt, we used a mathematical model for calculating the melting time developed by scientists of UrFU and IMET UB RAS. The model includes hydrodynamic and thermal parts. The hydrodynamic part of the model determines the speed of ferroalloys movement in relation to the melt of the processed metal, considering the forces acting on the alloys at each time point. The thermal part of the model is based on the classification of ferroalloys depending on the ratio of their liquidus temperature $\left(T_{l}\right)$, bath temperature $\left(\mathrm{T}_{b}\right)$ and crystallization of the iron-carbon melt $\left(\mathrm{T}_{c m}\right)$ into low-melting $\left(\mathrm{T}_{l} \leq \mathrm{T}_{c m}\right)$; refractory $\left(\mathrm{T}_{c m}<\mathrm{T}_{l}<\mathrm{T}_{b}\right)$ and ultra-refractory $\left(\mathrm{T}_{l} \geq \mathrm{T}_{b}\right)$. The course of the melting process is mainly determined by the temperatures ratio of $\mathrm{T}_{l}, \mathrm{~T}_{c m}, \mathrm{~T}_{b}$.

For the study, there were selected samples of complex nickel-containing ferroalloys with a composition corresponding to the alloys that can be smelted from domestic oxidized nickel ores $[22,23]$. The chemical composition of the samples and their thermophysical properties are presented in the table.

The simulation results are presented in Figures $1-3^{1}$. In the calculations, it was assumed that $\mathrm{T}_{c m}=1530^{\circ} \mathrm{C}$, the initial temperature of the ferroalloy $\mathrm{T}_{0}=25^{\circ} \mathrm{C}$, the temperature of the iron-carbon melt bath is $1600^{\circ} \mathrm{C}$; crystallization heat $\mathrm{L}=1,79 \cdot 10^{9}$ $\mathrm{J} / \mathrm{m}^{3}$, thermal conductivity coefficient of steel in the liquid state $\lambda=30 \mathrm{~W} / \mathrm{m} \mathrm{K}$ [24]. In real conditions, the initial temperature of a ferroalloy piece is always lower than the temperature of steel crystallization, and therefore a crust of solid steel [25 ] is formed 
TABLE 1: Chemical composition and thermophysical properties of ferroalloys at a temperature of $25^{\circ} \mathrm{C}$.

\begin{tabular}{|c|c|c|c|c|c|c|}
\hline \multirow[t]{2}{*}{ №. } & \multicolumn{2}{|c|}{ Composition*, \% } & \multirow{2}{*}{$\begin{array}{l}\text { Liquidus } \\
\text { temperature, } \\
{ }^{\circ} \mathrm{C}\end{array}$} & \multirow{2}{*}{$\begin{array}{c}\text { Thermal } \\
\text { conductivity, } \\
\text { W/(m.K) }\end{array}$} & \multirow{2}{*}{$\begin{array}{l}\text { Specific heat } \\
\text { capacity, } \\
\text { J/(kg.K) }\end{array}$} & \multirow{2}{*}{$\begin{array}{c}\text { Density, } \\
\mathrm{kg} / \mathrm{m}^{3}\end{array}$} \\
\hline & Si & $\mathrm{Ni}$ & & & & \\
\hline 1 & 5.1 & 10.3 & 1420 & 84 & 463 & 7420 \\
\hline 2 & 17.5 & 10.6 & 1220 & 93 & 496 & 6810 \\
\hline 3 & 31.4 & 10.0 & 1340 & 102 & 532 & 6190 \\
\hline 4 & 55.8 & 11.7 & 1210 & 119 & 596 & 4870 \\
\hline \multicolumn{7}{|c|}{ Note: ${ }^{*} \mathrm{Fe}-$ the rest. } \\
\hline
\end{tabular}

a

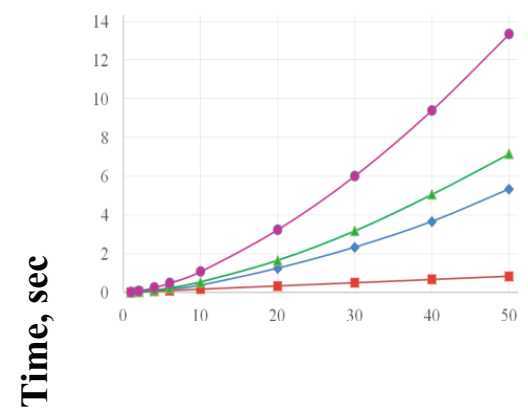

Diameter of alloy piece, $\mathrm{mm}$

c

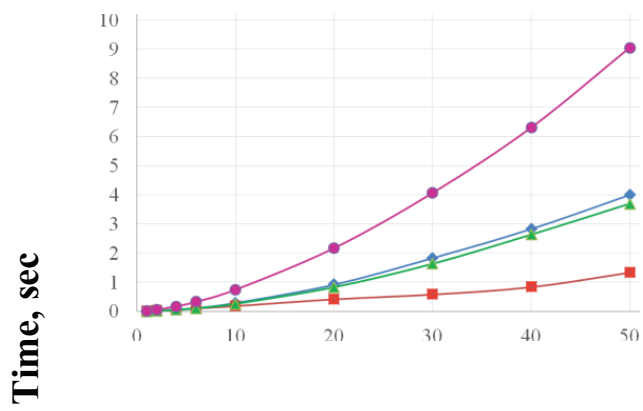

Diameter of alloy piece, $\mathrm{mm}$ b

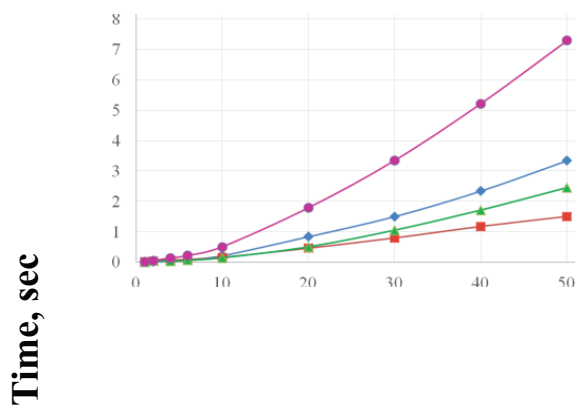

Diameter of alloy piece, $\mathbf{m m}$

d

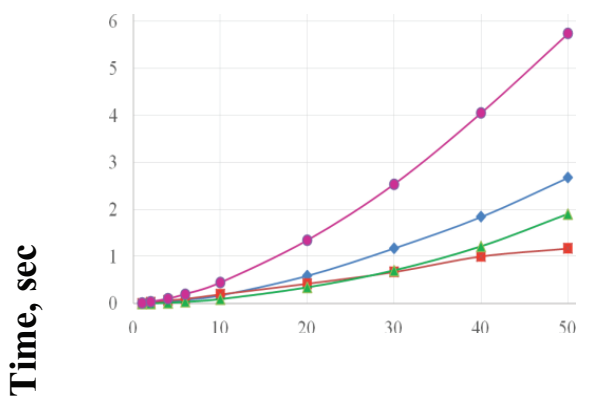

Diameter of alloy piece, $\mathrm{mm}$

\footnotetext{
$\rightarrow-$ time of the first melting period;

-- - time of the second melting period;

-- time of the third melting period;

$\rightarrow$ - total melting time
}

Figure 1: Dependence of the melting time for the periods of melting for nickel-containing ferroalloys on their fractional composition at $\mathrm{T}_{b}=1600^{\circ} \mathrm{C}$ : $\mathrm{a}$ - alloy $1 ; \mathrm{b}$ - alloy 2; c - alloy 3; $\mathrm{d}$ - alloy 4 (table).

on its surface. The following notation for the melting time is taken: $\tau_{1}, \tau_{2}, \tau_{3}$ are the duration of individual periods, $\tau$ is the total melting time. The thermal part of the model includes the differential Fourier thermal conductivity equation for each of the phases (crust, solid core, liquid ferroalloy layer), the number of which depends on the process 


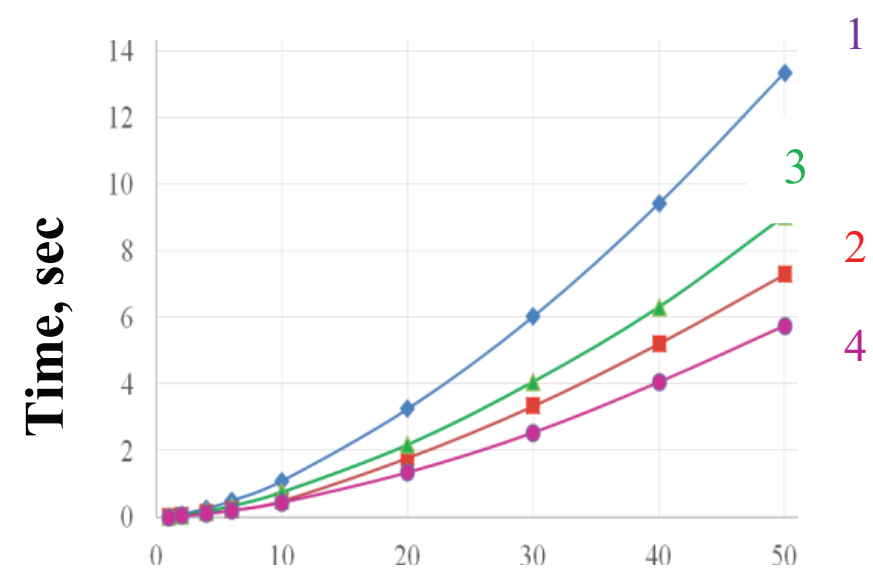

Diameter of alloy piece, $\mathrm{mm}$

Figure 2: Dependence of the melting time for ferroalloys on the fractional compositions at $\mathrm{T}_{b}=1600^{\circ} \mathrm{C}$; Curves numbers according to the alloys compositions in the Table.

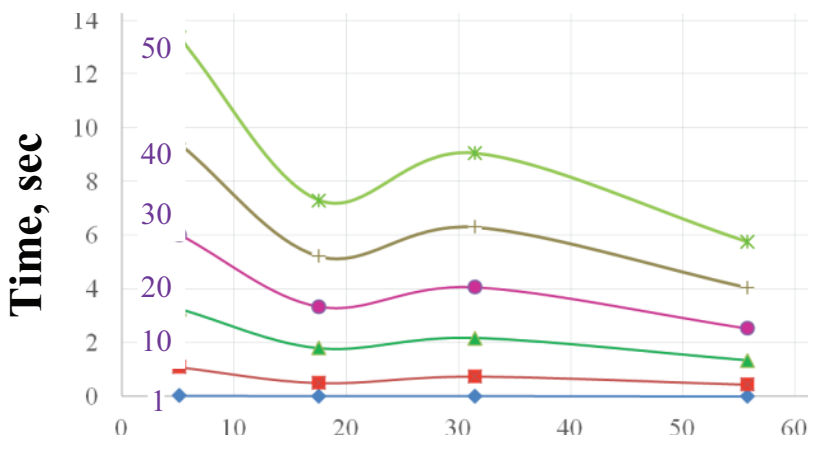

\section{Si content in alloy, $\%$}

Figure 3: Dependence of the melting time for ferroalloys on the Si composition for different fractions at $\mathrm{T}_{b}$ $=1600^{\circ} \mathrm{C}$; Numbers of curves equal to alloy fractions, $\mathrm{mm}$.

period and the type of ferroalloy, and the boundary conditions determined by convective heat transfer and melting process.

All the alloys under consideration belong to the group of low-melting ferroalloys (see table), in which $\mathrm{T}_{l} \leq \mathrm{T}_{c m}$. The process of their melting in an iron-carbon melt takes place in three periods. During the first period (Figure 1, $\tau_{1}$ ), the ferroalloy warms up and when the surface temperature reaches $T_{l}$, it begins to melt. In this case, pieces of ferroalloy are in the shell of solid steel, the thickness of which increases at the beginning of the period and decreases towards the end. The mass of the alloy piece at the beginning of the first melting period increases relatively quickly due to a significant temperature gradient at the boundary of the frozen crust with the alloy, then this process gradually slows down as it approaches the point $\mathrm{T}_{c m}$ where crystallization begins and completely stops when reaching this point. 
In the second period (Figure 1, $\tau_{2}$ ), the ferroalloy melts under a crust of solid steel due to the heat coming from the iron-carbon melt. It ends with the complete melting of the solid shell and with the contacting of the not melted, but sufficiently heated part of the ferroalloy piece with the liquid steel. The longer the first period, the more the crust of the freeze steel is heated and partially melted, which leads to the reduction of the second period share in the total melting time. For the studied alloys of all fractions, the second period is the least long, it takes no more than $20 \%$ of the total melting time.

In the third period (Figure 1, $\tau_{3}$ ), the solid piece of ferrosilicon nickel is melted, directly contacting with liquid steel. Theoretically, in periods 1, 2 there is no direct contact of the ferroalloy with liquid steel. Therefore, the interaction between the ferroalloy and the liquid metal (deoxidation reactions, mass transfer, etc.) is absent. The process of ferroalloy melting accelerates its movement in the iron-carbon melt.

The influence of the initial piece size is unambiguous: with increasing diameter, the total melting time increases (Figure 2). With an increase in the ferroalloy size up to 50 times (from 1 to $50 \mathrm{~mm}$ ), the total melting time increases up to $450-1800$ times.

An increase in the Si content from 5 to $18 \%$ in the considered alloys leads to a decrease in the melting time (Figure 3), a further increase in the $\mathrm{Si}$ concentration to 31\%, on the contrary, is accompanied by an increase in the melting time of the alloys, and a subsequent increase in $\mathrm{Si}$ to $53 \%$ leads to a smooth decrease of $\tau$. This is related to the liquidus temperatures values of the corresponding alloys (Table) and the possible formation in the region for silicon concentration of 17-23\% for low-melting $\mathrm{Fe}_{3} \mathrm{Si}$ and $\mathrm{Fe}_{5} \mathrm{Si}_{3}$ phases, characterized by a low liquidus temperature of $1261^{\circ} \mathrm{C}[26,27]$. It should be noted that the effect of the silicon concentration in the alloy on the total melting time increases significantly with increasing of ferroalloys fractional composition.

\section{Conclusion}

Thus, the work studied the melting kinetics of complex nickel-, silicon-containing ferroalloys in a steel melt. It is shown that an increase in the fraction of all the alloys under consideration from 1 to $50 \mathrm{~mm}$ leads to a stable increase in the melting time, and an increase in the silicon concentration from 5 to $18 \%$ reduces $\tau$, a further increase in the $\mathrm{Si}$ content to $31 \%$, on the contrary, is accompanied by an increase in $\tau$ of alloys, a following increase of $\mathrm{Si}$ content to $53 \%$ leads to a gradual reduction of $\tau$. In general, complex nickel-, silicon-containing ferroalloys are characterized by a much faster course of the melting process in steel compared to ferronickel. 


\section{Funding}

This work was supported by Project No. 18-5-2345-56 of the Integrated Program of the Ural Branch of the Russian Academy of Sciences.

\section{References}

[1] State report About the state and application of mineral - raw materials in Russian Federation in 2015 Nickel (Report No. 2016. p. 131 - 140). Moscow: «Mineral - Info».

[2] Zhuchkov V.I., Leontiyev L.I., Selivanov E.N. et al. (2014). Prospects for the production of stainless steel using domestic chrome and nickel ferroalloys, in Proceedings of the international sci-practical conference «Modern trends in the field of theory and practice of extraction and processing of mineral and man-made raw materials". Ekaterinburg: UMC UPI

[3] Zayakin O.V., Zhuchkov V.I. (2006). The obtaining of ferronickel from poor oxidized nickel ores. Stal', no 2, pp. 31-33.

[4] Boyarko G.Yu., Hat'kov V.Yu (2018). Commodity flows of ferroalloys in Russia. Cherniye Metally, no 3, pp. 60-68.

[5] Zhuchkov V.I., Zayakin O.V., Maltsev Yu.B. (2001). The development of the technology for processing poor oxidized Nickel ores. Proceedings "New technologies and materials in Metallurgy". Ekaterinburg.

[6] Zayakin O.V., Zhuchkov V.I. (2004) Technology of ferronickel production using the waste of aluminum industry. Proceedings of XII International Scientific Conference "Modern Problems of Steel Electrometallurgy". Chelyabinsk: SUSU.

[7] Zayakin O.V. (2002) Development of the Rational Composition and technology for the Production of Nickel - containing ferroalloys from poor oxidized Nickel Ores. PhD dissertation, IMET UB RAS

[8] Khalezov B.D., Zayakin O.V., Gavrilov A.S. et al. (2017). Hydro-, pyrometallurgical way for obtaining alloys of the system $\mathrm{Fe}-\mathrm{Ni}-\mathrm{Cr}-\mathrm{Mn}-\mathrm{Si}$. Butlerov communications, vol. 52, no. 10, pp. 111-117.

[9] Zayakin O.V., Zhuchkov V.I., Gal'perin L.L. (2004). Technology for the production of chromium-, nickelcontaining ferroalloys from Russian raw materials. Proceedings of the sci-practical conference "Chemistry and metallurgy: scientific and technical development for the industrial production", Ekaterinburg: "Philanthrop". 
[10] Zhuchkov V.I., Zayakin O.V., Lozovaya E.Yu. et al. (2016). Study of the melting process for the $\mathrm{Fe}-\mathrm{Ni}-\mathrm{Cr}$ system alloys in the carbon - iron melt. Butlerov communications, v. 47 , no. 8 , pp. $56-62$.

[11] Kazachkov I.P., Parimonchick I.V. (1973). Kinetics of ferroalloys melting. Izvestiya Vuzov. Chernaya Metallurgiya, no. 2, pp. 55-59.

[12] Agryropoulos S.A. (1984). Dissolution characteristics of ferroalloys in liquid steel. Iron and Steelmaker. no. 11, pp. 48-57.

[13] Zayakin O.V., Zhuchkov V.I., Lozovaya E. Yu. (2007). Time of melting for the nickelcontaining ferroalloys in steel. Izvestiya Vuzov. Chernaya Metallurgiya, no. 5, pp. $13-16$.

[14] Parimonchik I.B., Kazachkov I.P., Rezchik V.G. (1972). Simulation of the process for the ferroalloys dissolution in pouring ladle. Metallurgy and coke chemistry, no. 31, pp.62-65.

[15] Zhuchkov V.I., Zayakin O.V., Lozovaya E.Yu. et al. (2008). Study of the time of melting for the chromium containing ferroalloys in steel. Stal', no. 8, p. 75.

[16] Ohno R. (1982). Steady-state rates of dissolution of stationary iron, cobalt and nickel cylinders in liquid cooper. Metallurgical Transactions, v.13B, pp.175-183.

[17] Agryropoulos S.A., Guthrie R.I.L. (1981). The influence of high exothermic neats of dissolution on the solution of solid alloy additions into molten bath of steel. Heat and Mass Transfer in Metallurgical System, pp. 20-28.

[18] Aoki T. (1978). Bullet shooting: an improved method of Al and Ca addition. Iron and steel International, v. 51, no. 5, pp. 307-317.

[19] Seaton C.E., Rodrigues A.A., Gonzales V. et al. (1983). The Rate of Dissolution of Prereduced Iron in Molten Steel. Transaction ISIJ, vol. 23, pp.14-20.

[20] Guthrie R.I.L. and Gourtsoyannis L. (1971). Melting Rates of Furnace or Laddle Additions in Steelmaking. Canadian Metallurgical Quarterly, vol.10, no.1, pp.83-93.

[21] Ebneth G., Diener A., Plushkell W. (1978). Model computation on the injection of aluminum wire into steel melt. Arch. Eisenhutten, vol.49, no. 12, pp.563-568.

[22] Zayakin O.V., Zhuchkov V.I., Ostrovskiy Ya.I. (2008). The experience of the ferronickel production at "Serov Ferroalloys Plant". Proceedings of scientific conference "Theory and practice of ferroalloys production”. Nizhniy Tagil: «Media - print».

[23] Zayakin O.V., Zhuchkov V.I. (2011). Technological aspects for obtaining the nickelcontaining ferroalloys from poor oxidized nickel ores. Proceedings of international scientific-practical conference Abishev Readings - "Heterogeneous processes in enrichment and metallurgy". Karaganda: «Karaganda polygraphy ». 
[24] Zinoviev V.E. (1989). Thermophysical properties of metals at high temperatures. Moscow.: Metallurgiya.

[25] Zhuchkov V.I., Zayakin O.V., Maltsev Yu.B. (2001). Study of the temperatures of melting and density of nickel-containing ferroalloys. Rasplavy, no. 1, pp. 7-9.

[26] Bannyh O.A., Budberg P.B., Alisova S.P. et al. (1986). State diagram for binary and multicomponent systems based on iron. Moscow: Metallurgiya.

[27] Gasik M.I., Lyakishev N.P. (1999). Theory and technology of ferroalloys electrometallurgy. Moscow: Intermet Engineering. 